КУЛАГІН Д.О., к.т.н., доцент, професор кафедри електропостачання промислових підприємств,

КУЛАНІНА Є.В., к.т.н., старш. викл. кафедри електричних машин (Запорізький національний технічний університет)

\title{
Дослідження векторної системи керування тяговою асинхронною електропередачею дизель-поїзда
}

Подано результати аналізу векторної системи керування тяговою асинхронною електропередачею дизельпоїзда ДЕЛ-02. Показано, що спрощена лінійна модель працездатна при моделюванні різних режимів роботи тягового асинхронного електродвигуна, а завдяки використанню робастних методів керування отримано точні перехідні процеси.

Ключові слова: дизель-поїз, векторне керування, тяговий асинхронний електродвигун, лінійна модель.

\begin{abstract}
Постановка проблеми
Залізничний транспорт є однією з базових галузей сучасної економіки України. Стабільне та ефективне функціонування залізничного транспорту необхідне для забезпечення обороноздатності, національної безпеки і цілісності держави, підвищення якості життя населення. Виникнення проблем у діяльності та розвитку залізничного транспорту зумовлене рядом негативних факторів, зокрема прогресуючим старінням основних фондів [1].

Пріоритетним напрямком модернізації є розробка та втілення у виробництво сучасного вітчизняного дизель-поїзда 3 оптимальними енергозатратами [2]. Дизель-поїзд $\epsilon$ різновидом моторвагонного рухомого складу, що отримує енергію від дизеля. Він використовується в приміських перевезеннях на неелектрифікованих та частково електрифікованих залізничних лініях. В умовах модернізації рухомого складу залізниць світу та збільшення швидкостей руху дизель-поїздів понад 160 км/год все частіше використовується тягова електропередача змінного струму. До того ж дизель-поїзди з тяговою передачею змінного струму за тої самої маси, що й 3 іншими видами передач, розвивають більшу силу тяги, що дозволяє використовувати менше число моторизованих осей вагонів за тієї самої маси рухомого складу. Широко розповсюдженим $\epsilon$ використання в тягових електропередачах асинхронних двигунів (АД) 3 частотним регулюванням, яке має ряд суттєвих недоліків, такі як неможливість регулювання швидкості обертання та моменту без використання датчиків. Цю проблему значною мірою вирішує векторне керування. Цей метод керування дозволяє при використанні АД
\end{abstract}

(С Д. О. Кулагін, С. В. Куланіна, 2017 одержувати такі самі показники якості, як і двигуни постійного струму. Модернізація дизель-поїзда за допомогою векторного керування є актуальною темою для дослідження.

\section{Аналіз останніх досліджень і публікацій}

Проаналізувавши досвід використання дизельпоїздів ДЕЛ-02 та роботи 3 попередньої модернізації [3, 4, 5, 6], можна зробити висновок про високу надійність даної вітчизняної розробки та перспективність використання дизель-поїздів ДЕЛ-02.

Вирішення вказаних технічних проблем шляхом комплексної модернізації на основі досвіду синтезу та використання загальнопромислових та транспортних електроприводів дає змогу підвищити ефективність системи керування тяговою електропередачею дизельпоїздів ДЕЛ-02.

\section{Відокремлення нерозв'язаних раніше частин загальної проблеми}

Розробка систем керування складними об'єктами за допомогою асинхронного двигуна (АД) 3 векторним керуванням (ВК) ускладнена через взаємодію двох складних динамічних процесів, що відбуваються в АД з ВК і в технологічному об'єкті. Ця складність, в першу чергу, обумовлена численними нелінійностями в математичній моделі АД з ВК. Тому для подальшого дослідження доцільно використовувати спрощену лінійну модель, яка дозволяє проектувати за допомогою добре розроблених лінійних методів всю систему керування, що включає асинхронний двигун 3 векторним керуванням і складний об'єкт керування. За основу візьмемо відому модель, що описана в роботі [7]. Дана модель відрізняється простотою і точністю і дозволить дослідити різні режими роботи обраного двигуна за допомогою математичного моделювання. 
Мета роботи - аналіз векторної системи керування тяговою асинхронною електропередачею дизельпоїзда.

\section{Основний матеріал дослідження}

Метод імітаційного моделювання служить для дослідження електромеханічних процесів в складових частинах тягової електропередачі (перетворювачі частоти, тяговому двигуні, САК), що $є$ складним нелінійним об'єктом 3 певними змінами у часі топології схеми і параметрів їі складових елементів. Даний метод дозволяе пояснити функціональну структуру досліджуваних процесів, виявити істотні зв'язки із зовнішніми об'єктами, внутрішню організацію, оцінити кількісні характеристики тягової електропередачі [8].
Зважаючи на необхідність значних матеріальних вкладень для проведення експериментальних досліджень, високу вартість макетного та дослідного зразка тягової електропередачі, а також дорогі випробувальне устаткування i контрольновимірювальні прилади, використання імітаційного моделювання дозволяє не лише здешевити дослідження, знизити ї трудомісткість та терміни проведення, але і одночасно отримати інформацію про ряд параметрів тягового АД, які технічно ускладнені для їх безпосереднього вимірювання (потокозчеплення, електромагнітний момент, ковзання).

Для моделювання обрано тяговий асинхронний електродвигун АД906У1, паспортні дані якого наведено в табл. 1.

Таблиця 1

\begin{tabular}{|c|c|c|}
\hline Найменування параметра & $\begin{array}{c}\text { Умовне } \\
\text { позначення }\end{array}$ & $\begin{array}{c}\text { Значення в } \\
\text { абсолютних одиницях }\end{array}$ \\
\hline Номінальна потужність, кВт & $P_{H}$ & 240 \\
\hline Номінальна діюча фазна статорна напруга, В & $U_{s \phi H}$ & 665 \\
\hline Номінальний діючий фазний статорний струм, А & $I_{s \phi H}$ & 135 \\
\hline Номінальний діючий струм ротора, А & $I_{r \phi H}$ & 128 \\
\hline Номінальний діючий струм намагнічування, А & $I_{0 \phi H}$ & 36 \\
\hline Пусковий фазний струм, А & $I_{\phi . n y c \kappa}$ & 300 \\
\hline Номінальна частота статорної напруги, Гц & $f_{H}$ & 33,8 \\
\hline Номінальна частота обертання ротора, об/хв & $n_{H}$ & 1000 \\
\hline Номінальне абсолютне ковзання, \% & $S_{H}$ & 2 \\
\hline Момент інерції ротора, кгм² & $J$ & 21 \\
\hline Номінальне значення електромагнітного момента, Нм & $M_{H}$ & 2366 \\
\hline Активний опір статора, Ом & $R_{s}$ & 0,083 \\
\hline Активний опір ротора, Ом & $R_{r}$ & 0,068 \\
\hline Індуктивність розсіювання ротора, Гн & $L_{\sigma s}$ & 0,001615 \\
\hline Індуктивність розсіювання статора, Гн & $L_{\sigma r}$ & 0,001403 \\
\hline Індуктивність намагнічування, Гн & $L_{M}$ & 0,0866 \\
\hline Сумарна індуктивність намагнічування, Гн & $L_{\sigma}$ & 0,0029 \\
\hline Номінальний ККД, \% & $\eta_{H}$ & 93,7 \\
\hline
\end{tabular}

За основу візьмемо систему керування, описану авторами статті в роботі [6]. На рис. 1 подана функціональна електрична схема лінеаризованої системи АД 3 ВК, що складається 3 контура моментного струму i динаміки механічної частини системи. 


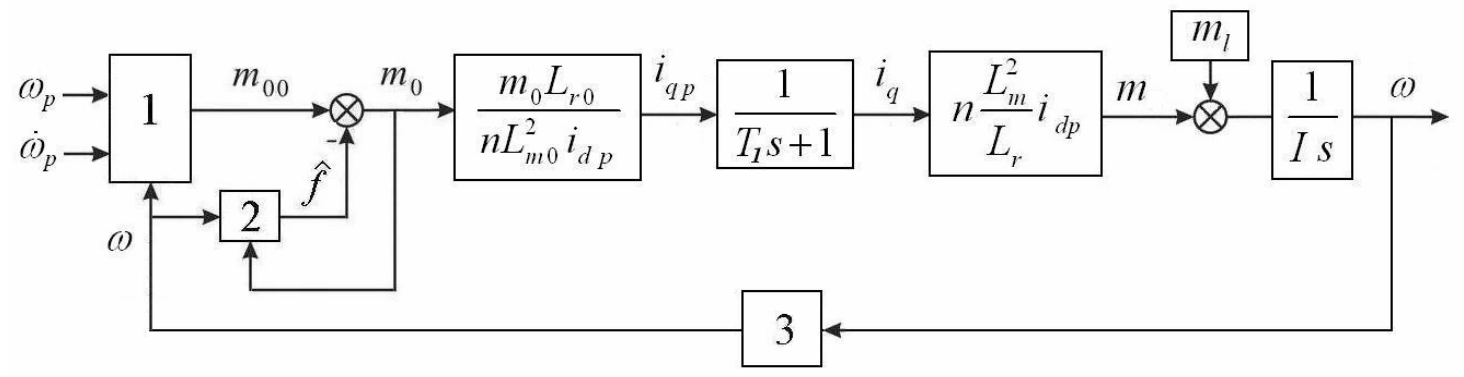

Рис. 1. Функціональна електрична схема лінеаризованої системи векторного керування асинхронним двигуном: 1 - блок формування виду перехідної характеристики; 2 - блок формування спостерігача невизначеності; 3 - асимптотичний диференціатор; $\omega, \omega_{p}, \alpha_{p}$ - швидкість ротора та ії програмне значення; $m, m_{0}$ - електромагнітний момент і його програмне значення;

$i_{d}, i_{d p}, i_{q}, i_{q p}-$ проекції вектора струму статора та їх програмні значення на осі базису $(d, q)$.

Комбінований регулятор моменту (КРМ) складається 3 керуючої (блок 1) та компенсуючої (блок 2) частин. КРМ формує програмний (бажаний) електромагнітний момент $m_{0}$. КРМ, на відміну від традиційного ПІ-регулятора, своєю компенсуючою частиною забезпечує робастність по відношенню до навантаження, збурень, невизначеності індуктивностей та приведеного моменту інерції ротора. Керуюча частина КРМ забезпечує заданий вид перехідного процесу.

Закон формування перехідної характеристики при керуванні кутовою швидкістю

$m_{00}=-k_{0}\left(\omega-\omega_{p}\right)+I_{0} \&_{p}$

Задача забезпечення робастності та високої точності рівняння полягає в оцінці невизначеності $f_{m}$ та іiі компенсації за допомогою спеціального доданку в законі керування. Невизначеність оцінюється за допомоги спостерігача

$$
\notin=-k\left(z+m_{0}+k I_{0} \nLeftarrow, \hat{f}_{m}=z+k I_{0} \nLeftarrow\right.
$$

Для компенсації впливу невизначеності задається комбінований закон керування у вигляді

$$
m_{0}=m_{00}-\hat{f}_{m}
$$

де $m_{0}-$ програмний електромагнітний момент.

Підстановка (3) дає

$$
I_{0}=m_{00}+f_{m}-\hat{f}_{m}
$$

При достатньо точному оцінюванні $\hat{f}$ невизначеності $f$ замість рівняння (4) можна вважати

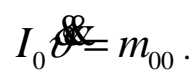

За допомогою моменту $m_{0} 3$ умови мінімуму споживаної потужності або постійності струму намагнічування формуються програмні струми $i_{d p}, i_{q p}$ в синхронному базисі.

Програмний моментний струм $i_{q p}$ визначається виразом

$i_{q p}=\frac{m_{0} L_{r 0}}{n L_{m 0}^{2} i_{d p}}$

Вирази $(7,6)$ в загальному випадку є нелінійними. Для лінеаризації доводиться оптимізувати електроспоживання для одного найбільш типового випадку $m_{0}$ (так роблять в усіх відомих системах векторного керування). В цьому випадку $i_{d p}$ буде постійним, а $i_{q p}$, згідно з (6), буде мати тільки одну змінну $m_{0}$, від якої буде залежати лінійно.

Номінальне значення магнітного момента

$m=n L_{m 0}^{2} L_{r 0}^{-1} i_{d} i_{q}$.

де $n$ - кількість пар полюсів,

$L_{r 0}, L_{m 0}-$ індуктивність ротора і взаємна індуктивність відповідно статора і ротора. 
Рівняння динаміки і регуляторів струмів набуває вигляду

$$
p\left(i-i_{p}\right)=-\left[\left(T_{s 0}^{\prime}\right)^{-1}+q\right]\left(i-i_{p}\right)
$$

За відсутності в законі керування похідної від програмного струму рівняння динаміки струмового контура виглядатиме так:

$$
p i=-\left[\left(T_{s 0}^{\prime}\right)^{-1}+q\right]\left(i-i_{p}\right)
$$

для якого передавальна функція від $i_{p}$ до $i$ визначається виразом

$$
W(p)=\frac{i}{i_{p}}=\frac{1}{\left[\left(T_{s 0}^{\prime}\right)^{-1}+q\right]^{-1} p+1}=\frac{1}{T_{1} p+1},
$$

де постійна часу $T_{1}=\left[\left(T_{s 0}^{\prime}\right)^{-1}+k_{0} q\right]^{-1}$.

Результати моделювання. Моделювання режимів роботи тягового асинхронного електродвигуна АД906У1 проводилось за допомогою програми MatLab Simulink. На рис. 2 зображено розгін двигуна під навантаженням до швидкості 1000 об/хв, потім здійснювалося гальмування до нульової швидкості. Рисунок ілюструє повний збіг програмного i отриманого значення швидкості.

Як видно з рис. 3, в момент пуску двигуна момент не перевищує двократного значення і далі знижується до номінального. Слід зазначити точний збіг програмного та отриманого значення. На рис. 4 показана зміна моментного струму. Завдяки робастним методам керування відсутні кидки при пуску двигуна.

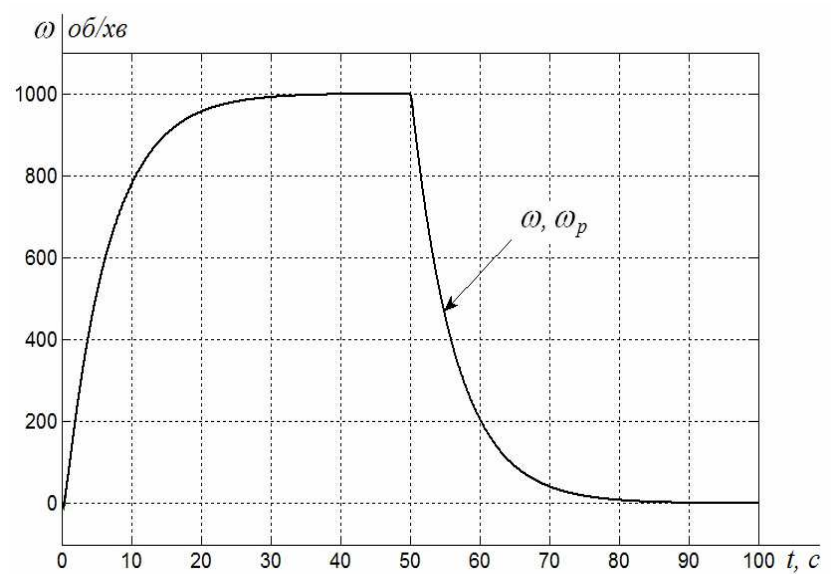

Рис. 2. Кутові швидкості $w$ АД

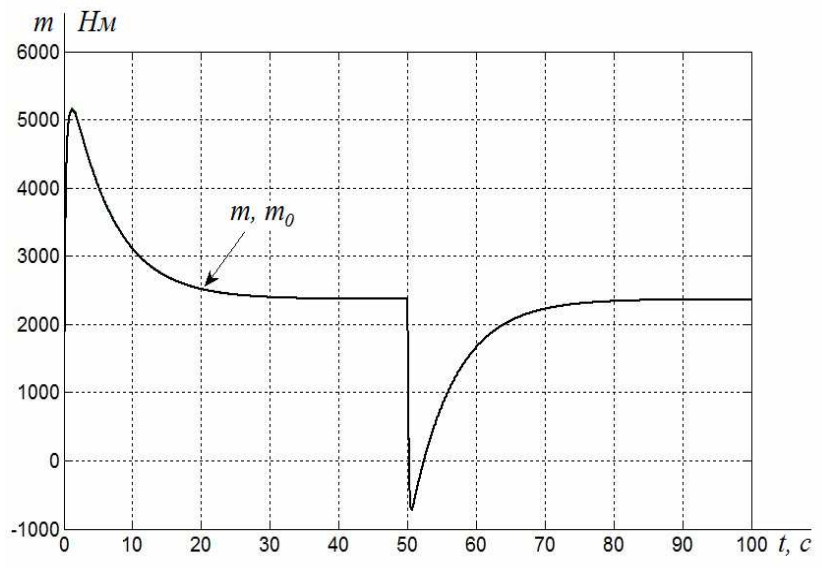

Рис. 3. Зміна електромагнітного момента $m$

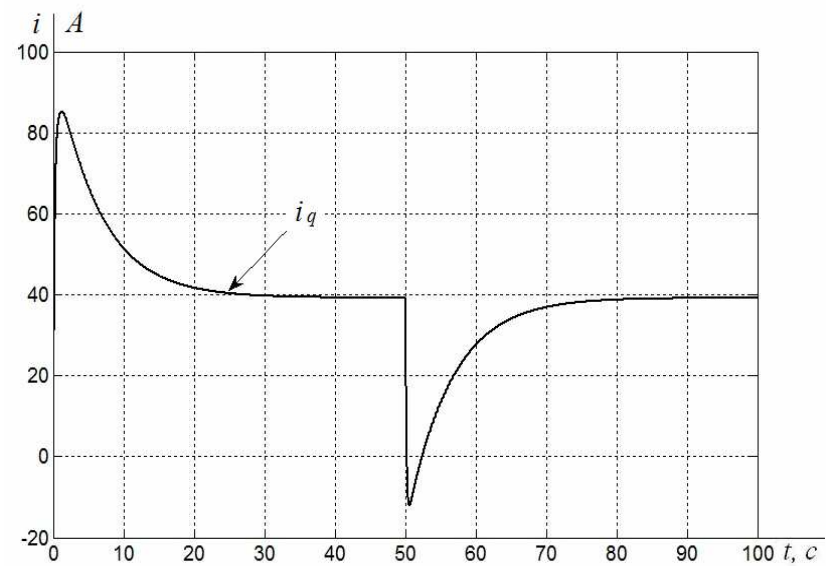

Рис. 4. Зміна моментного струму $i q$

Результати моделювання показали, що у всіх режимах роботи система векторного керування забезпечує добре відстеження заданої траєкторії. Також слід зазначити, що моделювання режимів роботи асинхронного двигуна за допомогою лінійної моделі вимагає на порядок менше часу, ніж моделювання повної моделі.

\section{Висновки}

1. Проведено аналіз векторної системи керування тяговою асинхронною електропередачею дизель-поїзда ДЕЛ-02 за допомогою комп'ютерного моделювання.

2. Моделювання режимів роботи тягового асинхронного електродвигуна АД906У1 показало, що лінійна модель $є$ працездатною для різних типів двигунів.

3. Завдяки використанню комбінованого регулятора момента та спостережників система $є$ робастною по відношенню до навантаження, збурень, невизначеності індуктивностей, приведеного моменту 
інерції ротора та забезпечує добрий вид перехідних процесів.

4. Отримані результати підтверджують доцільність подальшого дослідження модернізації дизель-поїзда за допомогою векторного керування.

\section{Список використаних джерел}

1. Кулагін, Д. О. Проектування систем керування тяговими електропередачами моторвагонних поїздів [Текст]: монографія / Д. О. Кулагін. Бердянськ, 2014. - 154 с.

2. Кулагін, Д. О. Розробка моделі модернізованого частотно-керованого тягового електроприводу зі змінним алгоритмом керування дизель-потяга ДЕЛ-02 [Текст] / Д. О. Кулагін, О. С. Качур, П. Д. Андрієнко // Електротехніка та електроенергетика. - 2010. - № 1. - С. 30-34.

3. Андрієнко, П. Д. Порівняльний аналіз регуляторів системи керування струмом тягового частотнокерованого електропривода дизель-поїзда ДЕЛ-02 [Текст] / П. Д. Андрієнко, Д. О. Кулагін, О.С. Качур // Електромашинобудування та електрообладнання. - 2010. - № 75. - С. 32-36.

4. Волков, А. В. Математическая модель многодвигательного частотнорегулируемого асинхронного электропривода дизель-поезда с векторной системой управления [Текст] / А. В. Волков, И. А. Орловский // Технічна електродинаміка. Тематичний випуск «Проблеми сучасної електротехніки». - 2008. - № 6. C. 31-36.

5. Кулагін, Д. О. Дослідження режиму гальмування дизель-поїзда ДЕЛ-02 [Текст] / Д. О. Кулагін // Вісник НТУ «ХПІ». - 2010. - № 28. - С. 408-409.

6. Kulagin D. O. Rolling electrical complex on the basis of the criterion of minimizing the area under the curve movement / Kulagin D. O. // Scientific Bulletin of National Mining University. - 2016. - № 2. C. 60-67.

7. Линейная динамическая модель асинхронного двигателя с векторным управленим [Текст] / Е. М. Потапенко, Е. В. Душинова, А. Е. Казурова [и др.] // Електротехніка та електроенергетика. 2010. - № 2. - С. 25-36.

8. Ситник, В.Ф. Імітаційне моделювання [Текст]: навч. посібник / В. Ф. Ситник, Н. С. Орленко. K., 1998. - 232 c.

Кулагин Д. А., Куланина Е. В. Исследование
векторной системы управления тяговй
асинхронной электропередачей дизель-поезда.
Приведены результаты анализа векторной системы
управления тяговой асинхронной электропередачей
дизель-поезда ДЕЛ-02. Показано, что упрощенная
линейная модель работоспособна при моделировании
различных режимов работы тягового асинхронного

электродвигателя, а благодаря использованию робастных методов управления получены точные переходные процессы.

Ключевые слова: дизель-поезд, векторное управление, тяговый асинхронный электродвигатель, линейная модель.

Kulagin D.A., Kulanina E.V. Investigation of vector control system for traction asynchronous electric power transmission of diesel train. The analyze with computer simulation of vector control system for traction asynchronous electric power transmission of the diesel train DEL-02 was conducted. The modeling of operating modes of the traction asynchronous electric motor has shown that the linear model is workable for various types of engines. The simulation results are shown in the figures and illustrate the complete coincidence of the program value and the resulting value of the angular velocity of the motor and the electromagnetic moment. Due to the use of a combined moment regulator and observers, the system is robust in relation to the load, disturbances, uncertainty inductance, reduced moment of inertia of the rotor and provides a good kind of transients. For example, the diagram of the change in the moment current illustrates the absence of a current surge during engine start-up. The obtained results confirm the expediency of further research the modernization of the diesel train using vector control.

Key words: diesel train, vector control, traction asynchronous electric motor, linear model.

Надійшла 31.07.2017p.

Kulagin D.O. Ph.D., Assistant professor, professor of the department «Electrosupply of the industrial enterprises» of Zaporozhye national technical University, Zaporizhzhya, Ukraine. E-mail: kulagindo@gmail.com

Kulanina E.V. Ph.D., Senior Lecturer of the department «Electrical machines» of Zaporozhye national technical University, Zaporizhzhya, Ukraine. E-mail: evkulanina@ukr.net

Кулагін Дмитро Олександрович, кандидат технічних наук, дочент, професор кафедри «Електропостачання промислових підприємств», Запорізький національний технічний університет, Запоріжжя, Україна. E-mail: kulagindo@gmail.com

Куланіна Свгенія Вікторівна, кандидат технічних наук, старший викладач кафедри «Електричні машини», Запорізький національний технічний університет, Запоріжжя, Украӥна. Е-mail: evkulanina@ukr.net 